\title{
Rasionalitas Muslim : Perilaku Konsumsi dalam Prespektif Ekonomi Islam
}

\author{
Dewi Maharani ${ }^{1}$, Taufiq Hidayat ${ }^{2}$ \\ ${ }^{1,2)}$ Fakultas Agama Islam, Universitas Muhammadiyah Banjarmasin \\ *Email korespondensi : dewimaharani@umbjm.ac.id
}

In the pursuit of economic activity, Islam porbids any elements related to it. Behavior of consumption in Islam is taught to In order for humans to consume their revenues or possessions for balance between the world and the next, by using the treasures earned to do good to fellow humans or other creatures on earth. The islamic view of economics is based on a paradigm of how to align people's interests more than personal ones. To see how consumption behavior in the perspective Islamic economics, the author wants to analyze rationally. The method used is library research because studies are focused on the materials Literature by poring over and studying the accepted literature.

Keywords: Rationality, Behavior, Consumption

Saran Sitasi: Maharani, D., Hidayat, T. (2020). Rasionalitas Muslim : Perilaku Konsumsi dalam Prespektif Ekonomi Islam. Jurnal Ilmiah Ekonomi Islam, 6(03), 409-412. doi: http://dx.doi.org/10.29040/jiei.v6i3.1374

DOI: http://dx.doi.org/10.29040/jiei.v6i3.1374

\section{PENDAHULUAN}

Rasionalitas ekonomi pada umumnya tidak dapat dipisahkan dari sistem ekonomi yang mendasarinya. Sistem ekonomi merupakan oraganisasi yang terdiri dari bagian-bagian yang saling terkait dan bekerja sama untuk mencapai tujuan ekonomi. Islam adalah ajaran yang mengatur kehidupan manusia dari berbagai unsur, baik dari segi aqidah, ibadah dan muamalah. Berdasarkan Mazhab Baqir as-Sadr ilmu ekonomi tidak pernah bisa sejalan dengan Islam. Ekonomi dan islam adalah dua hal yang berbeda, keduanya tidak dapat disatukan karena berbeda filosofi yang saling kontradiktif. Selama ini perbedaan-perbedaan yang mendasari ekonomi konvensional dengan ekonomi islam terletak pada orientasinya. Ilmu ekonomi konvensional menjadi bebas nilai (posivistik), sedangkan ekonomi islam dibangun atas dasar religius ( tauhid, keimanan, keadilan, kenabian dan khilafah) (Kambali, M. 2018).

Islam melarang umatnya untuk melakukan konsumsi secara berlebih-lebihan, namun islam mengajarkan bagaimana cara berprilaku dalam berkonsumsi secara proposional. Prilaku konsumsi yang berlebihan merugikan diri sendiri dan orang lain, karena pengeluaran pada pendapatan melebihi batas kemampuan. Di Indonesia presentase pengeluaran pangan masih sangat dominasi berada pada $49,14 \%$
(BPS, Susenas Maret 2019). Berdasarkan data terlihat bahwa masyarakat pada umumnya masih mementingkan pengeluaran untuk makanan.

Dalam presfektif rasionalitas konsumsi islam, pada saat rasionalitas konsumsi seseorang tinggi, maka keputusan untuk membeli berdasarkan keinginan bukan kebutuhan maka cenderung menurun, di karenakan orang tersebut berpikir rasional sehingga lebih mementingkan kebutuhan dari pada keinginan (Muhammad, 2004:152).

Berdasarkan uraian diatas, penulis ingin menganalisis Rasionalitas Muslim : Perilaku Konsumsi Dalam Prespektif Ekonomi Islam.

\section{METODE PENELITIAN}

Jenis penelitian ini menggunakaan tehnik pengumpulan data library research dikarenakan kajian difokuskan pada bahan-bahan kepustakaan dengan menelusuri, menelaah dan mencatat berbagai literatur sesuai dengan pokok pembahasan yang berstandar akademik. Pembahasan ini terintegrasi secara sintaksis, yaitu mengikuti aturan-aturan tertentu yang dapat di hubungkan secara logis satu dengan lainnya dengan data dasar yang diamati. ( Lexy J. Moleong,2000). 


\section{HASIL DAN PEMBAHASAN}

\section{a. Defenisi Rasionalitas}

Kata Rasionalitas akan terlihat membingungkan apabila memiliki makna atau arti yang banyak, dan terkadang rasionalitas tidak sesuai dengan apa yang diharapkan.

Rasionalitas merupakan pola pikir dalam bertindak sesuai dengan nalar dan logika manusia. Secara spesifik rasionalitas juga dapat dikatakan sebagai tendensi yang dilakukan untuk memenuhi rencana jangka panjang, dengan mempertimbangkan segala resiko dan manfaat dari tindakan yang dilakukan.

Rasionalitas adalah suatu konsekuensi atas dasar faktor ekonomi dan agama, dimana faktor utama menjadi landasan dasar dalam pembahasan mengenai perkembangan kapitalis. Rasionalitas memliki arti dan maksud yang berbeda-beda pada setiap orang, dimana seseorang membuat keputusan sendiri berdasarkan pada rasional masing-masing.

Dalam teori ekonomi modern, pelaku ekonomi dapat dikatakan rasional diantaranya, apabila keputusan yang diambil berdasarkan pada sikap dan keputusan yang diambil dilakukan secara konsisten, tahu bahwa sikap dalam bertindak lebih mengutamakan hal yang lebih penting dari pada sekedar keinginan serta sesuai dengan kemapuan yang dimiliki.

\section{b. Perilaku Konsumsi dalam Ekonomi Islam}

Konsumsi adalah salah satu kegiatan ekonomi dengan tujuan mengurangi atau menghabiskan manfaat suatu barang /jasa dalam memehuhi kebutuhan. Konsumsi pada hakikatnya adalah mengeluarkan sesuatu dalam rangka memenuhi kebutuhan (Furqon, I. K, 2018).

Dalam sistem perekonomian, konsumsi memiliki peranan penting yaitu mendorong terjadinya produksi dan distribusi. Perilaku konsumsi dalam ekonomi islam berdasarkan pada prinsip keadilan, prinsip kebersihan, prinsip kesederhanaan, kemurahan hati, dan moralitas. Konsumsi meliputi kebutuhan, kesenangan dan kemewahan. Kesenangan dibolehkan asal jangan berlebihan, tidak melampaui batas yang dibutuhkan oleh tubuh dan tidak pula melampaui batas-batas makanan yang dihalalkan sebagaimana dijelaskan dalam al-Qur'an surah al-A'raf ayat 31 yang artinya: "Wahai anak cucu Adam! Pakailah pakaianmu yang bagus pada setiap (memasuki) masjid, makan dan minumlah, tetapi jangan berlebihan sungguhnya Allah tidak menyukai orangorang yang berlebihan-lebihan".

Konsumsi bagi umat islam sebagai indikasi positif di dalam kehidupan sehari-hari untuk menjalankan aktivitas ibadah dan mentaati perintah Allah swt. Seorang umat muslim tidak akan merugikan dirinya didunia dan akhirat, karena melakukan sikap berlebih-lebihan dalam memenuhi kebutuhan, melakukan kesibukan di dunia sehingga melalaikan perintah Allah swt.

\section{c. Perspektif Islam Tentang Rasionalitas}

Sebelum membahas bagaimana konsep prespektif islam memandang tentang rasionalitas, alangkah lebih baik jika mengetahui konsep dasar rasionalitas menurut para ahli ekonom yang mengatakan bahwa suatu keputusan yang diambil manusia adalah bersifat rasional.

Menurut Kuper (2000) setiap orang yang memiliki pandangan yang berbeda-besa terkait dengan pengertian rasionalitas, namun pada dasarnya memiliki kesamaan secara fundamental. Kesamaan di istilahkan sebagai kepuasan. Setiap manusia cenderung ingin memuaskan dirinya, namun berbedabeda.

Rasionalitas dalam pandangan ekonomi konvensional sangat berbeda dengan ekonomi islam. Dimana, pandangan ekonomi konvensional mengganggap manusia dikatakan rasional ketika dapat memenuhi keinginannya yang bersifat materi. Sedangkan dalam pandangan ekonomi islam sangatlah berbeda, islam memandang seseorang dikatakan rasional apabila dapat memenuhi kebutuhan dan keinginannya.

Menurut Dagun (1992:2) konsep rasional manusia dalam ekonomi adalah kegiatan ekonomi sebagai kegiatan yang masuk akal. Rationality merupakan proses memaksimalkan kepuasan (utility maximization). Dalam proses memaksimalkan kepuasan memiliki batasan-batasan tertentu yang disebut dengan morality (Jody S. Kraus and Jules L. Coleman, 1987).

Dalam teori ekonomi modern, pelaku ekonomi diasumsikan rasional yaitu setiap orang selalu tahu apa yang mereka inginkan. (Rianto \& Amalia, 2010). Jika dalam ekonomi konvensional, memaksimumkan kepuasan (utility) konsumen dan keuntungan ubagi produsen, maka berbeda dengan ekonomi islam. Pelaku ekonomi islam baik produsen ataupun konsumen berusaha memaksimalkan mashlahah. 


\section{Jurnal Ilmiah Ekonomi Islam, 6(03), 2020, 411}

Rasionalitas dalam perilaku konsumsi secara perspektif islam sebagai berikut, (Dita Afrina \& Siti Achiria. 2019):

a. Perilaku konsumsi dikatakan rasional apabila dilakukan sesuai dengan kebutuhan dan kemampuan, sebagaimana dalam Al-Quran Surat Al-Israa ayat 29:

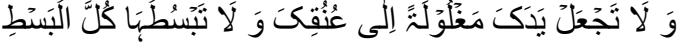

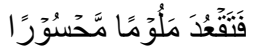

Artinya: Dan jamganlah kamu jadikan tanganmu terbelenggu pada lehermu dan janganlah kamu terlalu mengulurkannnya karena itu kami menjadi tercela dan menyesal.

b. Perilaku konsumsi dapat dikatakan rasional apabila tidak hanya dunia semata namun juga untuk keperluan akhirat, QS. Al- Israa ayat 26:

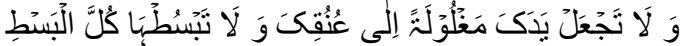

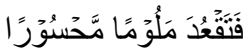

Artinya: Dan berikanlah kepada keluargakeluarga yang dekat akan haknya, kepada orang miskin dan orang yang dalam perjalanan dan janganlah kamu menghambur-hamburkan (hartamu) secara boros.

c. Perilaku konsumsi dikatakan rasional karena memiliki tingkat konsumsi yang lebih kecil karena terkait pada kehalalan, umat muslim hanya diperbolehkan mengkonsumsi hal-hal yang bersifat halal dan thayib. Qs. Al- Baqarah ayat 173:

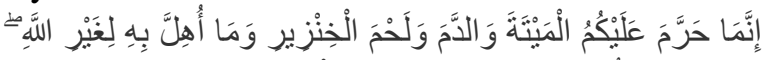

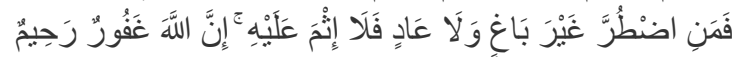

Artinya: Sesungguhnya Allah hanya mengharamkan bagimu bangkai, darah, daging babi, dan binatang yang (ketika disembelih) disebut (nama) selain Allah. Tetapi barangsiapa dalam keadaan terpaksa (memakannya) sedang dia tidak menginginkannya dan tidak (pula) melampaui batas, maka tidak ada dosa baginya. Sesungguhnya Allah Maha Pengampun lagi Maha Penyayang.

d. Perilaku konsumsi dikatakan rasional apabila seseorang tidak menimbun hartanya dalam bentuk kekayaan namun melakukan ivestasi dalam rangka meningkatkan pertumbuhan ekonomi.

Islam adalah agama yang syarat terhadap etika, etika dalam islam dapat dikelompokkan menjadi 6 aksioma yaitu, tauhid, keadilan, kebebasan, berkehendak dan pertanggungjawaban halal dan sederhana (Naqvi, 1985). Manusia harus bertidak rasional karena manusia memiliki kelebihan dibandingkan makhluk lain ciptaan Allah Swt. Allah Swt memberikan manusia akal agar dapat digunakan untuk berfikir secara rasional. Manusia dianggap berlaku rasional apabila perilaku dalam mencapai kepuasan maksimal (utility maximization) sesuai dengan syariat islam.

\section{d. Rasionalitas Konsumsi dalam Prespektif Ekonomi Islam}

Perilaku manusia dalam konsumsi pada pemahaman konvensional dianggap rasional namun belum tentu dianggap rasional dalam pandangan islam. Konsumsi dianggap rasional dalam islam apabila pembelajaan yang dilakukan sesuai dengan kebutuhan dan kemampuan yang dimiliki, sesuai dengan Qs. Al.Israa, yang artinya: "Dan janganlah kamu jadikan tanganmu terbelenggu pada lehermu dan janganlah kamu terlalu mengulurkan karena itu kami menjadi tercela dan menyesal". Perilaku konsumsi yang lain seperti membelanjakan hartanya di jalan Allah, membelanjakan sesuatu sesuai dengan kebutuhannya dengan memperhatikan syariat islam.

Kegiatan konsumsi yang dilakukan manusia merupakan kegiatan pokok yang harus di lakukan dalam sendi kehidupan manusia. Kegiatan tersebut tidak hanya berkaitan dengan kebutuhan pokok saja namun juga terkait dengan sandang dan papan. Manusia harus bersikap rasional dalam berkonsumsi, jangan menjadi konsumen yang konsumtif. Secara umum konsumsi adalah sebagai penggunaan barang dan jasa untuk memenuhi kebutuhan manusia. Dalam ekonomi islam, konsumsi memilik arti yang hampir sama dengan ekonomi konvensional. Konsumsi adalah bagian aktivitas ekonomi selain produksi dan distribusi. konsumsi lahir karena adanya permintaan akan barang dan jasa. Namum, permintaan akan muncil karena adanya keinginan dan kebutuhan oleh konsumen rill ataupun konsumen potensial (Masykuroh, 2008).

Menurut para pakar maqashid kebutuhan dibagi menjadi beberapa bagian, yaitu (Jenita \& Rustam, 2017):

Pertama, Kebutuhan Dharuriyat (Primer)

Adalah kebutuhan yang menjadi dasar kehidupan manusia yang baik dengan agama maupun dunia. Kebutuhan ini harus terpenuhi agara manusia bisa hidup layak. Apabila kebutuhan ini tidak terpenuhi maka akan menggangu kehidupan manusia. 


\section{Jurnal Ilmiah Ekonomi Islam, 6(03), 2020, 412}

Kedua, Kebutuhan Hajjiyat (Sekunder)

Kebutuhan Hajjiyat adalah kebutuhan setelah kebutuhan primer, karena ini adalah kebutuhan penguat. Apabila kebutuhan ini tidak terpenuhi maka tidak akan mengancam keselamaatan kehidupan umat manusia namun dapat mengalami kesulitan dalam melakukan kegiatan. Dimana kebutuhan ini untuk mempermudah manusia sesuai dengan perubahan zaman dan proses kehidupan.

Ketiga, Kebutuhan Tahsiniyat / Kamaliyat (Tersier/Pelengkap)

Kebutuhan yang sama sekali tidak mengancam salah satu hal pokok dalam kebutuhan primer. Kebutuhan ini muncul setelah terpenuhinya kebutuhan dharuriyat (Primer) dan Hajjiyat (Sekunder).

Dalam prespektif ekonomi islam terdapat penyeimbang dalam kehidupan, berbeda dengan ekonomi konvensional. Di jelaskan di dalam al-quran penyeimbang dalam ekonomi islam salah satunya dengan mengeluarkan zakat, sedekah dan infaq. Hal ini merupakan rantai umat islam agar terjalin solidaritas umat muslim dalam berkontibusi saling membantu antara satu dengan yang lain.

\section{KESIMPULAN}

Berdasarkan hasil penelitian yang dilakukan, bahwasanya kegiatan ekonomi dalam islam tidak diperbolehkan mencampuradukkan antara yang halal dan haram, karena terkait pada prilaku konsumsi. Dalam prilaku konsumsi harus memperhatikan rasionalitasnya agar kebutuhan yang ingin dipenuhi memiliki batasan-batasan sesuai dengan kemampuan yang dimiliki.

Dalam penelitian ini, penulis menyarankan pengembangan penelitian selanjutnya dapat diperdalam lagi dengan metode studi kasus. Atau dengan penelitian kuantitatif yaitu melakukan survei terhadap masyarakat mengenai suatu kasus tertentu.

Penulis mengucapkan terimakasih kepada seluruh civitas akademik yang telah memberikan kontribusinya terhadap penyelesaian penelitian kami, dan penulis juga memohon maaf apabila masih terdapat banyak kekurangan pada naskah penelitian yang dilakukan oleh penulis.

\section{DAFTAR PUSTAKA}

(Afrina, 2019; Arief, 2012; Furqon, 2018; Habibullah, 2018; Jenita \& Rustam, 2017; Kraus \& Coleman, 1987; S., 2014)(Arief, 2012; Kambali, 2018; Sitepu, 2016; Wigati, 2011)

Afrina, D. (2019). Rasionalitas Muslim Terhadap Perilaku Israf Dalam Konsumsi Perspektif Ekonomi Islam. EkBis: Jurnal Ekonomi Dan Bisnis. https://doi.org/10.14421/ekbis.2018.2.1.1088

Arief, S. (2012). Konsumen Rasional dalam Perspektif Islam. Islamic Economics Journal.

Cahyani, D. I., \& Sumadi, S. (2015). Alternatif Sistem Ekonomi Islam Untuk Indonesia Yang Lebih Sejahtera. Jurnal Ilmiah Ekonomi Islam, 1(02).

Furqon, I. K. (2018). TEORI KONSUMSI dalam ISLAM. Adzkiya : Jurnal Hukum Dan Ekonomi Syariah.

https://doi.org/10.32332/adzkiya.v6i1.1169

Habibullah, E. S. (2018). ETIKA KONSUMSI DALAM ISLAM. Ad Deenar: Jurnal Ekonomi Dan Bisnis Islam. https://doi.org/10.30868/ad.v1i01.230

JENITA, J., \& RUSTAM, R. (2017). KONSEP KONSUMSI DAN PERILAKU KONSUMSI ISLAM. Jurnal Ekonomi Dan Bisnis Islam UIN Imam Bonjol.

Kambali, M. (2018). Relevansi Pemikiran Ekonomi Muhammad Baqir Ash-Sadr. JES (Jurnal Ekonomi https://doi.org/10.30736/jesa.v3i1.35

Kraus, J. S., \& Coleman, J. L. (1987). Morality and the Theory of Rational Choice. Ethics. https://doi.org/10.1086/292886

S., A. B. (2014). ETIKA KONSUMSI DALAM PERSPEKTIF EKONOMI ISLAM. In HUNAFA: Jurnal Studia Islamika.

Sitepu, N. I. (2016). Prilaku Bisnis Muhammad SAW Sebagai Entrepreneur Dalam Filsafat Ekonomi Islam. Human Falah.

Wigati, S. (2011). PERILAKU KONSUMEN DALAM PERSPEKTIF EKONOMI ISLAM Oleh : Sri Wigati (Dosen Fakultas Syariah IAIN Sunan Ampel Surabaya). PrilakuKonsumen.

Kartini Kartono, Pengantar Metodologi Research, ALUMNI, Bandung, 1998, hlm.78

M. Nur Rianto Al Arif \& Euis Amalia. (2010).Teori Mikroekonomi. Jakarta: Prenada Media Group

Muhammad Baqir as-Sadr, Iqtishaduna (Our Economics), Teheran: WOFIS, 1983/1403 H.

Naqvi, Syed Nawab Haidar (1985), Etika dan Ilmu Ekonomi, Suatu Sintesis Islami, Bandung,Mizan 